\title{
Evaluating the utilisation of Climate-Smart Agriculture (CSA) technologies and practices among smallholder farmers in The Lawra, Jirapa and Nandom districts of Ghana
}

\author{
K.O. SAM*, V.A. BOTCHWAY, N. KARBO, G.O. ESSEGBEY, D. K. NUTSUKPO \\ \& R.B. ZOUGMORÉ
}

(K. O. S, V. A. B. \& N. K.: CSIR-Animal Research Institute, P. O. Box AH 20, Achimota, Accra, Ghana; G. O. E.: CSIR-Science Technology Policy Research Institute, Accra, Ghana; D. K. N.: Ministry of Food and Agriculture (MOFA), Volta Region, Ho, Ghana \& R. B. Z.: International Crops Research Institute for the Semi-Arid Tropics (ICRISAT), Bamako, Mali) *Corresponding author's email: kingsam704@yahoo.co.uk

\begin{abstract}
Climate change is posing threat to agriculture in sub-Saharan Africa including Ghana. Climate-Smart Agriculture (CSA) is proposed to solve climate change impacts on agriculture. Smallholder farmers are adopting various strategies to be resilient to climate change effects. Empirical research is required to evaluate CSA utilisation in Ghana. Lawra, Jirapa and Nandom districts in the climate-risk areas of Guinea Savannah agro-ecological zone were chosen and Participatory Rapid Appraisal (PRA) tools were used. Farm budget analysis and market price methods were employed; key financial decision-making tools were net returns, profit margins and benefit-cost ratio. Soft systems content analysis, frequencies, means, ranking and data aggregation were employed to generate results. CSA use in the study districts was smallholder driven and male dominated. CSA was mainly used for staples including cereals and legumes and small ruminants under livestock. Crop-livestock integration and crop rotation were the common CSA practices with the highest costs $(\mathrm{GH} \phi 6,370.00)$ and highest revenues $(\mathrm{GH} \phi 9,460.00)$ respectively. Utilisation of CSA in the districts is beneficial and investments are profitable and financially viable. All actors and stakeholders must join forces to promote CSA in the districts. Rigorous promotional campaigns, capacity building and funding at all levels are crucial for CSA adoption in Ghana.
\end{abstract}

Keywords: Climate-Smart Agriculture; Smallholder Farmers; Food Security; Livelihood; Lawra, Jirapa and Nandom Districts

Original scientific paper. Received 13 Oct 2020; revised 14 Dec 2020

\section{Introduction}

Climate change continues to pose a major threat to economic growth and development globally. This threat to sub-Saharan Africa, especially West Africa, is compounded by their weak economies and high dependence on agriculture as a major driver of economic growth and development. Ghana is equally threatened because agriculture is deeply dependent on climatic elements such as rainfall, temperature, wind speed and sunshine. Ghana's agricultural sector continues to play a vital role in the

Ghana Jnl Agric. Sci. 55 (2), 122 - 144

GJAS is an Open Access Journal and distributed under the terms of the Creative Commons (CC) License [CC BY 4.0] 
national development by way of employment, income, food and nutrition, and inputs or raw materials and therefore has a great impact on poverty reduction. Though currently declining, the sector's contribution to national gross domestic product (GDP) is very phenomenal. It recorded GDP decline from $19.7 \%$ in 2018 to $18.5 \%$ in 2019 (GSS, 2020).

Climate change in the form of increased temperatures and unpredictable rainfall patterns impacts negatively on Ghana's agriculture and the people's livelihoods. Such impacts include increase in crop yield gaps, increase in postharvest losses of agricultural commodities, decline in the availability and quality of forage and high mortality and morbidity of livestock (Essegbey et al., 2020). Some major crops in Ghana; example cassava, maize, sorghum, rice and yam are currently experiencing yield gaps. Though experiencing low yields, productivity of these crops is expected to further decline due to climate change (Issahaku et al., 2014). Cassava yields are expected to reduce by $3 \%, 13.5 \%$ and $53 \%$ in the years 2020, 2050 and 2080 respectively (Asante \& Amuakwa-Mensah, 2015). Freduah et al. (2019) also projected reduction in maize yields in the interior savannah of Ghana. Groundnut productions are however projected to increase due mainly to carbon dioxide fertilization (Adiku et al., 2015; De Pinto et al., 2012). For livestock systems in the country, Thornton et al. (2015) indicated that Aboveground Net Primary Productivity (ANPP) in rangelands, which is a good proxy for livestock productivity, is projected to decrease by $47.9 \%$ in Ghana by 2050.

Ghana has since 2010 undertaken several initiatives towards the development of comprehensive programmes (strategies) as part of processes leading to enhancing national adaptation to climate change (GCCAFS, 2014; Sam et al., 2015). A National Climate Change Policy (NCCP) has been developed focusing on achieving a climate-resilient and climate-compatible economy while achieving sustainable development (MESTI, 2013). Consequently, a National Climate-Smart Agriculture Action Plan has been developed to operationalize the agriculture sector of the NCCP (MoFA, 2015).

Indisputably, the ever-increasing human population in sub-Saharan Africa including Ghana tends to fuel food requirements; and food production needs to increase logically. The impacts of climate change are expected to further reduce agricultural productivity and food systems. To address the challenges of climate change impacts on agriculture and the food system, Climate Smart Agriculture (CSA) concept is increasingly being promoted. The recent global and national drive for ClimateSmart Agriculture seems to present a scenario that CSA is the best option and remedy for climate change impacts on agriculture (CIAT, 2016). CSA integrates the three dimensions of sustainable development (economic, social and environmental) by jointly addressing food security and climate challenges. It is built on three main pillars namely: (1) sustainably increasing agricultural productivity and incomes; (2) adapting and building resilience to climate change and (3) reducing and/or removing greenhouse gas emissions, where possible (FAO, 2013).

FAO (2015) affirmed that CSA is an approach to developing the technical, policy and investment conditions to achieve sustainable agricultural development for food security under climate change. Anuga et al. (2019) also asserted that CSA provides adaptation strategies that can help avoid or ameliorate the negative 
impacts of climate change on production, incomes and well-being of smallholder farmers. In this vein CSA, as an approach, is assumed to facilitate farmers to operate along its three pillars. Nonetheless, farmers are doing their own thing to stay in business; employing various adaptation strategies intended to be resilient to climate change. Meanwhile, there is a great paucity of CSA information at the local level, particularly the technical (practices) and the investment (finance) aspects. Andrieu et al. (2017) asserted that a major challenge for policymakers to operationalize CSA is the identification, valuation (cost-benefit), and subsequent prioritization of climate-smart options and portfolios (groups of CSA options) for investment. FAO (2013) also documented that smallholder farmers, including livestock keepers, fishers and foresters, especially women and indigenous people, are the most vulnerable to climate change. Business-asusual strategies therefore may not yield the needed livelihood support for the smallholder farm families. Rather could increase their risk and vulnerability to climate change shocks and stresses. Key issues considered include the level of CSA utilisation among farmers, the costs and benefits, constraints and challenges, contributions of CSA use to livelihood improvement and the support systems required to promote CSA in the study districts.

The study mainly intended to evaluate the utilisation of CSA technologies and practices among smallholder farmers in the Lawra, Jirapa and Nandom districts of Ghana. Focusing on this, the study specifically sought to:

- Assess the utilization levels of CSA technologies and practices in the Lawra, Jirapa and Nandom districts.
- Estimate the costs and benefits associated with the use of the CSA technologies and practices in the study area.

- Assess the contribution of the CSA use to livelihood improvement of the users.

- Identify key challenges associated with the use of CSA technologies and practices in the study area. Highlight the support systems required to promote CSA adoption in the study area.

In 2014, the Ghana Science-Policy Dialogue Platform on Climate Change, Agriculture and Food Security (CCAFS) profiled the CSA technologies and practices in the Guinea Savannah zone of Ghana. As CSA is known to be location-specific (FAO, 2015), making available empirical evidence from the district level is worthwhile to support effective CSA policy and investment decision-making and actions. CSA actors will find the document very useful; particularly agricultural extension agents, NGOs and farmer-based organisations could use the findings for education, planning and as capacity building instruments. As a guide, the study will capacitate farmers with knowledge and skills towards resilience building and farm-level investment decisionmaking. It contributes to information gap filling and adds up to the existing scanty body of knowledge on CSA in Ghana.

\section{Materials and Methods}

Multifaceted approaches and methods were employed to conduct the study. The process issues have been summarised to capture the 
main activities and strategies, selection of study area, data collection, and data analysis.

\section{Planning and consultative meetings}

Series of planning meetings were held to design and implement the study. A multidisciplinary team of researchers with expertise in agricultural economics, agribusiness, climate science, agronomy, animal husbandry, range ecology, policy and development economics as well as monitoring, evaluation and learning was deployed for the purpose.

\section{Selection of study area}

In 2014, the Ghana CCAFS SciencePolicy Platform profiled over 50 CSA technologies and practices in the Guinea Savannah agro-ecological zone of Ghana (Karbo et al., 2016). The prevalence of the CSA technologies and practices was highlighted during the CSA profiling exercise in the zone. This guided the selection of the study districts as some communities emerged as more CSApracticing areas. Attention was given to the prevalence of CSA technologies and practices within a locality as most people practice more than one CSA technology or practice. Proximity and accessibility were considered vis-à-vis the resources available (time and finance). In general, the study prioritised geographical areas with ongoing CSA technologies and practices. MoFA office in the Upper West region was contacted to assist in the selection process. The agricultural extension zones and major CSA practicing communities within the selected districts were considered in the study.

Three districts within the Guinea Savannah agro-ecological zone were purposefully selected; namely Lawra, Jirapa and Nandom districts located in the Upper West region of Ghana. Lawra and Jirapa are known CCAFS project districts (Sijmons et al., 2013) with ongoing CSA technologies and practices, which made it easy to work with the existing structures. Nandom district was selected based on proximity, accessibility, language similarities and convenience. Besides, the rippling effects in CSA use and the longstanding history and ties with the two CCAFS districts influenced Nandom's inclusion.

\section{Profile of the Lawra, Jirapa and Nandom districts}

The Lawra, Jirapa and Nandom districts form part of the 11 districts in the Upper West region of Ghana and lie in the north-western part of the region. They are adjacent districts within the Guinea Savannah agro-ecological zone of Ghana. The climate involves high temperatures, uni-modal rainfall patterns and long periods of dry conditions. Soils are generally poor within the districts. There are dominant rural population and are described as agrarian districts. Table 1 presents a summary profile of study area districts. 


\section{TABLE 1}

Profile of the Lawra, Jirapa and Nandom Districts

\begin{tabular}{|c|c|c|c|}
\hline Feature & Lawra District & Jirapa District & Nandom District \\
\hline $\begin{array}{l}\text { Location and } \\
\text { size }\end{array}$ & $\begin{array}{l}\text { Between Longitude } \\
2^{\circ} 25^{\prime} \mathrm{W} \text { and } 2^{\circ} 45^{\prime} \mathrm{W} \text { and } \\
\text { Latitude } 10^{\circ} 20^{\prime} \mathrm{N} \text { and } \\
11^{\circ} 00^{\prime} \mathrm{N} \text { with area of } \\
1051.2 \mathrm{~km}^{2} . \text { Is made up of } \\
98 \text { communities with } 95 \% \\
\text { living in rural areas. }\end{array}$ & $\begin{array}{l}\text { Between Longitudes } 2^{\circ} 20 \mathrm{~W} \text { and } \\
2^{\circ} 50^{\prime} \mathrm{W} \text { and Latitudes } 10^{\circ} 25^{\prime} \mathrm{N} \text { and } \\
11^{\circ} 00^{\prime} \mathrm{N} \text { with area of } 1188.6 \mathrm{~km}^{2} \text {. Is } \\
\text { made up of } 137 \text { communities with } \\
95 \% \text { living in rural areas. }\end{array}$ & $\begin{array}{l}\text { Between Longitude } 2^{\circ} 25 \mathrm{~W} \\
\text { and } 2^{\circ} 45^{\prime} \mathrm{W} \text { and Latitude } \\
10^{\circ} 20^{\prime} \mathrm{N} \text { and } 11^{\circ} 00^{\prime} \mathrm{S} \text { with } \\
\text { area of } 567.6 \mathrm{~km}^{2} \text {. Is made up } \\
\text { of } 88 \text { communities with } 86 \% \\
\text { living in rural areas. }\end{array}$ \\
\hline Capital. & Lawra. & Jirapa. & Nandom. \\
\hline Climatic zone. & $\begin{array}{l}\text { Guinea Savannah zone } \\
\text { with tropical continental } \\
\text { climate. }\end{array}$ & $\begin{array}{l}\text { Guinea Savannah zone with } \\
\text { tropical continental climate. }\end{array}$ & $\begin{array}{l}\text { Guinea Savannah zone with } \\
\text { tropical continental climate. }\end{array}$ \\
\hline Temperature & $\begin{array}{l}\text { Mean annual temperature } \\
\text { ranging between } 27^{\circ} \mathrm{C} \text { to } \\
36^{\circ} \mathrm{C} \text {. }\end{array}$ & $\begin{array}{l}\text { Mean annual temperature ranging } \\
\text { between } 28^{\circ} \mathrm{C} \text { and } 31^{\circ} \mathrm{C}\end{array}$ & $\begin{array}{l}\text { Mean annual temperature } \\
\text { ranging between } 27^{\circ} \mathrm{C} \text { to } \\
36^{\circ} \mathrm{C} \text {. }\end{array}$ \\
\hline Rainfall & $\begin{array}{l}\text { Uni-modal rainfall pattern } \\
\text { Single maximum rainfall. } \\
\text { Rainy season is from } \\
\text { May to October. Mean } \\
\text { annual rainfall is } 1016 \mathrm{~mm}- \\
1270 \mathrm{~mm} \text {. }\end{array}$ & $\begin{array}{l}\text { Uni-modal rainfall pattern. Single } \\
\text { maximum rainfall. Rainy season is } \\
\text { from May to October. Mean annual } \\
\text { rainfall is } 1000 \mathrm{~mm}-1100 \mathrm{~mm} \text {. }\end{array}$ & $\begin{array}{l}\text { Uni-modal rainfall pattern. } \\
\text { Single maximum rainfall. } \\
\text { Rainy season is from May } \\
\text { to October. Mean annual } \\
\text { rainfall is } 916 \mathrm{~mm}-1246 \mathrm{~mm} \text {. }\end{array}$ \\
\hline Vegetation & $\begin{array}{l}\text { Guinea Savanna short } \\
\text { grasses and few woody } \\
\text { plants. Common trees are } \\
\text { drought and fire resistant } \\
\text { trees (baobab, dawadawa, } \\
\text { Shea trees and acacia). }\end{array}$ & $\begin{array}{l}\text { Guinea Savanna woodland with } \\
\text { light undergrowth and scattered } \\
\text { medium-sized trees, shrubs } \\
\text { and grasses. Common trees are } \\
\text { dawadawa, Shea, baobab, neem. }\end{array}$ & $\begin{array}{l}\text { Guinea Savanna grasses with } \\
\text { scattered fire resistant trees } \\
\text { such as the Shea and baobab } \\
\text { trees. Mango and cashew } \\
\text { trees are also found in the } \\
\text { district. }\end{array}$ \\
\hline $\begin{array}{l}\text { Relief and } \\
\text { Drainage }\end{array}$ & $\begin{array}{l}\text { Gently rolling with a few } \\
\text { hills }(180 \mathrm{~m}-300 \mathrm{~m}) \text { above } \\
\text { sea level. Main river is the } \\
\text { Black Volta with several } \\
\text { tributaries. }\end{array}$ & $\begin{array}{l}\text { Generally flat and low-lying with } \\
\text { average height of } 300 \mathrm{~m} \text { above } \\
\text { sea level. Few plateau surfaces } \\
\text { ranging between } 1000-1150 \text { feet. } \\
\text { Major rivers are White Volta and } \\
\text { tributaries of the Black Volta }\end{array}$ & $\begin{array}{l}\text { Gently undulating. Located } \\
\text { about } 180 \mathrm{~m} \text { above sea } \\
\text { level with a few isolated } \\
\text { hills. Poorly endowed } \\
\text { with water bodies, but few } \\
\text { interconnected streams flow } \\
\text { into the Black Volta, which } \\
\text { cuts through the district. }\end{array}$ \\
\hline Soils & $\begin{array}{l}\text { Mainly of laterite soils. } \\
\text { There are strips of alluvial } \\
\text { soils along the flood plains } \\
\text { of the Black Volta and } \\
\text { sandy loams along some of } \\
\text { its tributaries. }\end{array}$ & $\begin{array}{l}\text { Mainly sandy loam with } \\
\text { underlying hard iron pans. There } \\
\text { are narrow strips of alluvial soils } \\
\text { along the numerous dry valleys of } \\
\text { the tributaries of the Black Volta. }\end{array}$ & $\begin{array}{l}\text { Mainly sandstone, gravel, } \\
\text { mudstone, alluvium, granite } \\
\text { and shale weathered into } \\
\text { different soil grades. Erosion } \\
\text { is resulting into sand, clay } \\
\text { and laterite ochroslols soils. }\end{array}$ \\
\hline
\end{tabular}




\begin{tabular}{|c|c|c|c|}
\hline Feature & Lawra District & Jirapa District & Nandom District \\
\hline$\overline{\text { Population }}$ & $\begin{array}{l}\text { Estimated population for } \\
2020 \text { is } 67,886 \text { comprising } \\
32,998(49 \%) \text { males and } \\
34,888(51 \%) \text { females. } \\
\text { Population density is about } \\
65 \text { persons } / \mathrm{km}^{2} \text {. Rural } \\
\text { population is } 86 \% \text {. }\end{array}$ & $\begin{array}{l}\text { Estimated population for } 2020 \text { is } \\
109,308 \text { comprising } 52,093(48 \%) \\
\text { males and } 57,215(52 \%) \text { females. } \\
\text { Population density stands at } 92 \\
\text { persons } / \mathrm{km}^{2} \text {. Rural population is } \\
86 \%\end{array}$ & $\begin{array}{l}\text { Estimated population for } \\
2020 \text { is } 56,947 \text { comprising } \\
27,924(49 \%) \text { males and } \\
29,023(51 \%) \text { females. } \\
\text { Population density is } \\
100 \text { persons } / \mathrm{km}^{2} . \text { Rural } \\
\text { population is } 86 \% \text {. }\end{array}$ \\
\hline $\begin{array}{l}\text { Main } \\
\text { Economic } \\
\text { Activity }\end{array}$ & $\begin{array}{l}\text { Agriculture is the main } \\
\text { economic activity and } \\
\text { accounts for } 80 \% \text { of } \\
\text { the District economy. } \\
\text { Commerce /Service and } \\
\text { industry account for } \\
\text { about } 18.2 \% \text { and } 0.8 \% \\
\text { respectively. Industrial } \\
\text { activities are mainly } \\
\text { processing of agricultural } \\
\text { produce, are agro-based } \\
\text { and small in size. }\end{array}$ & $\begin{array}{l}\text { Agriculture is the main economic } \\
\text { activity. About } 71 \% \text { of the working } \\
\text { population are into agriculture and } \\
\text { related activities. } \\
\text { Dominant industries are small- } \\
\text { scale manufacturing and agro- } \\
\text { processing. Commerce is chiefly } \\
\text { buying and selling of agricultural } \\
\text { produce, consumer goods and } \\
\text { second-hand items. }\end{array}$ & $\begin{array}{l}\text { Agriculture is the main } \\
\text { economic activity and } \\
\text { accounts for about } 85 \% \text { of } \\
\text { the labour force. Commerce/ } \\
\text { service is } 14 \% \text { and industry } \\
\text { is } 1 \% \text {. A lot of industries } \\
\text { are agro-based and small in } \\
\text { size. Activities include local } \\
\text { brewing, commercial food } \\
\text { preparation, Shea butter and } \\
\text { groundnut oil extraction, rice } \\
\text { processing, weaving, etc. }\end{array}$ \\
\hline Agriculture & $\begin{array}{l}\text { Major crops include maize, } \\
\text { millet, rice, sorghum, yam, } \\
\text { groundnut, cowpea, soya } \\
\text { beans, and vegetables. } \\
\text { Shea nut and dawadawa } \\
\text { trees are main cash crops. } \\
\text { Livestock are goats, sheep, } \\
\text { cattle, poultry (local) and } \\
\text { pigs, rabbit, grass-cutter } \\
\text { and beehives. }\end{array}$ & $\begin{array}{l}\text { Major crops include maize, } \\
\text { sorghum, millet, rice, groundnuts, } \\
\text { cowpea, soya beans and yam. } \\
\text { Cashew and mango as main cash } \\
\text { crops cultivated. Tree crops like } \\
\text { dawadawa and Shea are naturally } \\
\text { grown on farms. Major livestock } \\
\text { are poultry (local), goats, pigs, } \\
\text { sheep and cattle. }\end{array}$ & $\begin{array}{l}\text { Major crops include rice, } \\
\text { sorghum, millet, maize, } \\
\text { soybean, cowpea, groundnut, } \\
\text { bambara groundnut, yam and } \\
\text { sweet potato and vegetables. } \\
\text { Main cash crops include } \\
\text { cotton, pepper and economic } \\
\text { trees (Shea, dawadawa and } \\
\text { baobab). Livestock are cattle } \\
\text { goat, rabbit, sheep, poultry } \\
\text { (local) and pigs. }\end{array}$ \\
\hline Markets & $\begin{array}{l}\text { Main markets Lawra } \\
\text { and Babile. Other small } \\
\text { markets are Eremon, } \\
\text { Boo, Baseble, Tuopare, } \\
\text { Domwine, and Zambo. }\end{array}$ & $\begin{array}{l}\text { Major markets are Jirapa, Tizza, } \\
\text { Sabuli, Hain and Ullo. There are } \\
\text { other minor markets across the } \\
\text { communities. }\end{array}$ & $\begin{array}{l}\text { Main markets are Kuturu } \\
\text { (Baseble), Ko and Nandom. } \\
\text { Hamile market near Burkina } \\
\text { is noted for informal cross } \\
\text { border agricultural trade. }\end{array}$ \\
\hline $\begin{array}{l}\text { Financial } \\
\text { Institutions }\end{array}$ & $\begin{array}{l}\text { Two functional banks } \\
\text { serving as main financial } \\
\text { institutions are namely: } \\
\text { Ghana Commercial Bank, } \\
\text { Lawra Area Rural Bank } \\
\text { and First National Bank. }\end{array}$ & $\begin{array}{l}\text { Main financial institutions are } \\
\text { Sonzele Rural Bank Ltd with an } \\
\text { agency in Han, Sinapi Aba Trust } \\
\text { Ltd, GN Bank and the St. Joseph's } \\
\text { Credit Union also situated in } \\
\text { Jirapa. }\end{array}$ & $\begin{array}{l}\text { Main financial institutions } \\
\text { are Nandom Rural Bank and } \\
\text { GN Bank in Nandom. } \\
\text { Several groups exist, which } \\
\text { have adopted the Village } \\
\text { Savings and Loans Schemes. }\end{array}$ \\
\hline $\begin{array}{l}\text { Institution } \\
\text { supporting } \\
\text { Agriculture }\end{array}$ & $\begin{array}{l}\text { Department of agriculture, } \\
\text { CCAFS West Africa, } \\
\text { District CSA Platforms, } \\
\text { CIKOD, etc. }\end{array}$ & $\begin{array}{l}\text { Department of agriculture, } \\
\text { CCAFS West Africa, District CSA } \\
\text { Platforms, etc. }\end{array}$ & $\begin{array}{l}\text { Department of agriculture, } \\
\text { CCAFS West Africa, } \\
\text { District CSA Platforms, } \\
\text { NANDIRDEP, etc. }\end{array}$ \\
\hline
\end{tabular}

Source: Authors' Compilation from Jirapa District (2014), Lawra District (2014), Nandom District (2014), Jirapa Municipal Assembly (2018), Lawra Municipal Assembly (2018), Nandom District Assembly (2018) and https://statsghana.gov.gh/ 


\section{Data collection}

Research instruments and protocols were developed and pre-tested by the team. Both qualitative and quantitative data were collected in order to gather and generate adequate information. Participatory CSA Rapid Appraisal (PRA) tools were used to collect field data. These include key informant interviews, focus group discussions, community group meetings and interviews, critical observations, proportional piling, scoring and ranking. Before the actual fieldwork, adequate community entry processes were followed to sensitize and create awareness to gain acceptance. A total of 45 respondents from the districts were purposefully selected and interviewed for cogeneration of information. The selection covered all the agricultural zones and CSA practicing communities. The participants were CSA practitioners in the respective districts who have adequate knowledge and information on the subject. They include the policy and decision makers from the assemblies, selected workers of government departments and agencies, agricultural extension agents, traditional leaders, NGOs and FBOs workers and individual farmers. The survey was conducted between October and November 2015. Participants were interviewed on the farm operations using a checklist and interview guide with selected crops and livestock.

At the community meetings and interviews, each district was made to select the CSA technologies and practices utilized in the district from the existing list profiled by the Ghana CCAFS Science-Policy platform (Karbo et al., 2016). This was done based on the fact that CSA is location, area and site-specific (FAO, 2013; MoFA, 2015). The districts were subsequently guided to prioritize the most suitable and commonly used CSA technologies and practices using the Participatory CSA Profiling Manual (Sam et al., 2015). The manual has CSA scoring matrix, which contains sieves of criteria with corresponding weights according to the Likert's scale. Each selected CSA technology or practice was evaluated and scored using the weighted criteria. CSA technologies and practices that score highest was highly prioritized or ranked followed by the next in that order. Top five CSA technologies and practices were selected as the most highly prioritised and superior for each district.

Detailed primary data were collected on use of CSA technologies and practices, which include general information about the study sites, level and scale of CSA use, gender issues in CSA use, anticipated costs and benefits, productivity associated with the CSA practices, input and output market prices, challenges and constraints, among others. Community group meetings and interviews were used to determine the magnitudes of CSA Utilization, prioritize the CSA technologies and practices, identify the main cost items and the major farm commodities involved. Data on the use of CSA technologies and practices by scale and by gender and the contributions of CSA use to livelihood improvement were collected through proportional piling. Challenges and constraints associated with the use of CSA technologies and practices were identified using the proportional piling and simple or pair-wise ranking tools. The experts or key informants' interviews and community meetings also enumerated some support systems necessary to promote CSA within the districts.

Most data were generated in focus group discussions (FGDs) setting. The FGDs comprising 12 participants and in-depth interviews with three key informants were 
conducted in each study district. Separate FGDs were conducted for farmers and the other CSA actors in each district. The repeated FGDs helped in the verification and correction of data gaps as well as build consensus on conflicting data. The interviews with the selected experts provided further data for the study. Data on costs and benefits (revenues) was derived from primary data collected from key resource farmers, experts' opinions and from published work or reports. The data from the literature review was used to fill in the data gaps generated by the primary data collection.

\section{Data processing and presentation of results}

Data generated from the fieldwork were adequately discussed in various meetings and subjected to soft systems of analysis based on consensus building. Adequate content analysis techniques were employed to analyse the data collected in the focus group discussions and expert interviews. Voice recordings obtained were transcribed and manually synthesised to retrieve information to complement the data. Frequency distributions, arithmetic means, scoring, ranking and relevant data compilation and aggregation were used to generate useful results. Net return or worth, profit margins and benefit-cost ratios were employed as key financial decision-making tools to assess CSA investment decisions among the farmers.

Farm budget analysis and market price methods were used to compute the costs and revenues and the related total costs and total revenues associated with the use of the top five CSA technologies and practices in each district. These were in turn used to compute the net financial returns or worth, profit margin and benefit-cost ratio regarding the utilization of the selected CSA technologies and practices. All costs and benefits were computed on per acre basis and every CSA technology or practice was considered separately. Three major farm produce or commodities were used for each selected CSA technology or practice. MicroSoft Excel Version 16 was used to capture and analyse the data.

Theoretical framework on the financial analysis

The financial analysis is based on two economic theories namely the theory of production and cost theory. Under the theory of production, the goal of the firm is profit maximization and the prices of the output and inputs are given. In the cost theory, the total cost is split into total fixed cost and total variable cost. Fixed costs are costs that do not change (vary) with the level of output. Variable costs are costs that change directly with output (Koutsoyiannis, 1979; Dyson, 1997; Boake-Yiadom, 2004; Nwokoye \& Ilechukwu, 2018). In this study, fixed costs include tools and equipment, animal pens and land acquisition/rent. Variable costs include planting materials, animal breeds, animal feed, labour, transportation and training.

\section{Assumptions made for the financial analysis}

The following assumptions were made in the estimation of financial costs and benefits.

- CSA users are smallholder farmers operating land sizes of at most 5 hectares

- CSA users are in business and are rationally aiming at profit maximisation

- Only one season's output is used for the selected farm commodities

- Time was considered as a constant due to one season period

- Farm gate prices were used to compute costs and benefits 
- Monetary values were not discounted, considering one season and timeless operation, hence zero year period

\section{Estimation of costs}

In the cost estimation approach, cost is explained as the monetary value of the goods and services purchased or utilized. Thus monetary valuation of all efforts, materials, resources, time and utilities consumed, risk incurred and opportunities forgone in production and delivery of goods and services (Nwokoye \& Ilechukwu 2018). In this regard cost is the product of price and quantity of the cost item used. Total cost describes the summation of all the costs that are incurred to produce something or to utilize services (LaRock, 2019 and Ghawate, 2020). Simply put, total cost is the sum of the costs of all of the various factors or cost items involved.

To compute the total cost (TC) associated with the use of a particular CSA technology or practice various cost items under the use of that CSA technology or practice were identified. Also, the unit prices for each cost item were collected from the commodity budget of the Department of Agriculture in the districts. Knowing the physical quantities of each cost item used, the cost (C) of using a particular input was computed. The process was repeated for all the inputs (in both variable and fixed costs) associated with that CSA technology or practice. The resultant costs were aggregated to obtain the total cost (TC) associated with the use of that particular CSA technology or practice. This process is expressed mathematically in the following equations.

$$
\mathbf{C}=\mathbf{P}_{\mathbf{c}} \cdot \mathbf{Q}_{\mathrm{c}}
$$

where $\mathbf{P}_{\mathbf{c}}$ and $\mathbf{Q}_{\mathbf{c}}$ are the respective price and quantity of a specific cost item associated with the use of that CSA technology or practice.
Total Variable Cost (TVC): is the summation of the various variable cost components of the economic activities. This is given as:

TVC $=\mathrm{C}_{\mathrm{v} 1}+\mathrm{C}_{\mathrm{v} 2}+\ldots \ldots \ldots+\mathrm{C}_{\mathrm{vJ}} \ldots \ldots \ldots \ldots$. [2] where $\mathbf{C}_{\mathbf{v} 1}, \mathbf{C}_{\mathbf{v} 2}, \ldots . . . ., \mathbf{C}_{\mathrm{vJ}}$ are the various variable cost elements associated with the use of that CSA technology or practice.

Total Fixed Cost (TFC): is the summation of the various fixed cost elements. This can be represented as:

TFC $=\mathrm{C}_{\mathrm{f} 1}+\mathrm{C}_{\mathrm{f} 2}+\ldots \ldots \ldots .+\mathrm{C}_{\mathrm{fJ}} \ldots \ldots \ldots \ldots \ldots$ [3] where $\mathbf{C}_{\mathrm{f1}}, \mathbf{C}_{\mathrm{f} 2}, \ldots . . . ., \mathbf{C}_{\mathrm{fJ}}$ are the various fixed cost items associated with the use of that CSA technology or practice.

Rewriting equations 2 and 3 in general terms give equations 4 and 5 respectively.

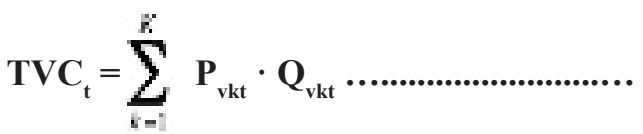

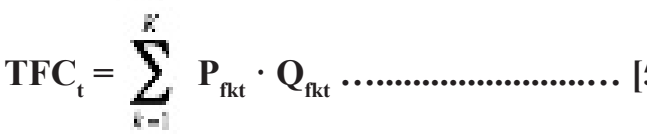

Total Cost (TC) is shown as in equation 6.

$\mathrm{TC}_{\mathrm{t}}=\sum_{k=1}^{K} \mathbf{P}_{\mathrm{vkt}} \cdot \mathbf{Q}_{\mathrm{vkt}}+\sum_{k=1}^{K} \mathbf{P}_{\mathrm{fkt}} \cdot \mathbf{Q}_{\mathrm{fkt}} \ldots \ldots . .6[6]$ where $\mathbf{k}$ is the number of various cost items in the respective variable costs and fixed costs and takes the values of $\mathbf{k}=\mathbf{1}, \mathbf{2}, \ldots . . . ., \mathbf{K}$. $\mathbf{t}$ denotes the time period in years (one season and timeless implies zero years). These processes were repeated for the other prioritised CSA technologies and practices. 


\section{Estimation of benefits (revenues)}

In estimating the benefits derived from the use of CSA technologies or practices, revenues were used as proxy indicators.

Revenue (R) is the payment received from selling a good or performing a service, hence revenue is a product of price and quantity (Koutsoyiannis 1979) as shown in equation 7.

$\mathbf{R}=\mathbf{P}_{\mathrm{s}} \cdot \mathbf{Q}_{\mathrm{s}}$

where Ps and Qs are the respective price and quantity of a specific farm commodity produced using a particular CSA technology or practice.

Total Revenue (TR) is therefore the summation of various revenues generated from the respective farm produce or commodities as shown in equation 8 .

$\mathbf{T R}=\mathbf{R}_{1}+\mathbf{R}_{2}+\ldots \ldots \ldots \ldots+\mathbf{R}_{\mathrm{n}}$

where $\mathbf{R}_{1}, \mathbf{R}_{2}, \ldots \ldots \ldots . . ., \mathbf{R}_{\mathrm{n}}$ are the revenues generated from various farm commodities produced from using that CSA technology or practice.

Rewriting equation 8 in general terms gives equation 9.

$\mathbf{T} \mathbf{R}_{\mathrm{t}}=\sum_{z=1}^{Z} \mathbf{P}_{\mathrm{pzt}} \cdot \mathbf{Q}$

where $z$ is the number of farm commodities and takes the values of $\mathbf{z}=\mathbf{1}, \mathbf{2}, \ldots \ldots ., \mathbf{Z}$. $\mathbf{t}$ denotes the time period in years (one season and timeless implies zero years). These processes were repeated for the other prioritised CSA technologies and practices.

Net financial returns or worth, profit margin and benefit-cost ratio

The Net Return or Worth (П), Profit Margin (PM) and Benefit-Cost Ration (BCR) were used to estimate the profitability of the various prioritized technologies. Net return or worth, which shows the difference between the expected benefits (revenues) and the associated costs (Gittinger, 1982 and Boakye-Yiadom, 2004), is as shown in equation 10. Profit Margin is shown in equation 11, while BenefitCost Ratio is shown in equation 12.

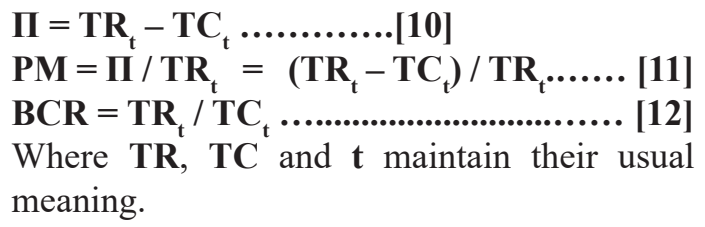
meaning.

The Net Return or Worth (П) indicates if there is a gain or loss from the investment into a particular CSA technology or practice. A positive net return or worth $(\Pi>0)$ indicates a gain and a negative net return or worth $(\Pi$ $<0$ ) indicates a loss from investment into a particular CSA technology or practice.

The Profit Margin (PM) shows if an investment is profitable or not. An investment into a particular CSA technology or practice is profitable when the profit margin is greater than zero but less than or equal to one $(0<\mathrm{PM}$ $\leq 1)$ and not gainful when the profit margin is less than or equal zero $(\mathrm{PM} \leq 0)$.

The Benefit-Cost-Ratio (BCR) confirms if an investment is financially viable or not. An investment into a particular CSA technology or practice is financially viable when the benefitcost ratio is greater than one $(\mathrm{BCR}>1)$ and not financially viable when the benefit-cost ratio is less than one $(\mathrm{BCR}<1)$.

\section{Results and Discussion}

This section focuses on the empirical results and findings, which are presented in accordance with the study districts. 
Utilization levels of CSA technologies and practices.

\section{Magnitudes of CSA utilization}

A total of 28,30 and 38 CSA technologies and practices were identified in the Lawra, Jirapa and Nandom districts respectively (Table 2). These districts were found using in common 22 CSA technologies and practices, which may be due largely to the rippling effects in CSA use since they are adjacent districts. The main differences were that, Jirapa was using fodder banking, farmermanaged natural regeneration, mulching, halfmoon and Zai technology and beekeeping. Lawra was not using guinea fowl ethnoveterinary health management, drip irrigation, talking book, Essoko Ignitia Ltd information dissemination and contour ploughing/farming. Only Nandom was using all the identified CSA technologies and practices including crop insurance and cage fish farming.

TABLE 2

CSA Technologies and Practices Used in Lawra, Jirapa and Nandom Districts

\begin{tabular}{|c|c|c|c|c|}
\hline No. & Name of CSA technology/practice & Lawra & Jirapa & Nandom \\
\hline $\begin{array}{l}1 \\
2 \\
3\end{array}$ & $\begin{array}{l}\text { Agro-forestry } \\
\text { Mixed farming } \\
\text { Crop rotation }\end{array}$ & $\begin{array}{l}\sqrt[V]{V} \\
\sqrt{ }\end{array}$ & $\begin{array}{l}\sqrt[V]{ } \\
\sqrt{ } \\
\text { V }\end{array}$ & $\begin{array}{l}\sqrt[V]{ } \\
\sqrt{ }\end{array}$ \\
\hline $\begin{array}{l}4 \\
5 \\
6\end{array}$ & $\begin{array}{l}\text { Mixed cropping } \\
\text { Cover cropping } \\
\text { Stone lining (bonding) }\end{array}$ & $\begin{array}{l}\sqrt{ } \\
\sqrt{ } \\
\sqrt{ }\end{array}$ & $\begin{array}{l}\sqrt{ } \\
\sqrt{ } \\
\sqrt{ }\end{array}$ & $\begin{array}{l}\sqrt{ } \\
\sqrt{ } \\
\sqrt{ }\end{array}$ \\
\hline $\begin{array}{l}7 \\
8 \\
9 \\
10 \\
11 \\
12 \\
13 \\
14 \\
15 \\
16 \\
17 \\
18 \\
19 \\
20 \\
21 \\
22 \\
23 \\
24 \\
25 \\
26 \\
27 \\
28 \\
29 \\
30 \\
31 \\
32 \\
33 \\
34 \\
35 \\
36 \\
37 \\
38\end{array}$ & $\begin{array}{l}\text { Earth Bonding } \\
\text { Tie ridging } \\
\text { Ridge contouring } \\
\text { Community-led bushfire control } \\
\text { Crop livestock integration } \\
\text { Crop diversification } \\
\text { Planting climate resilient crop varieties } \\
\text { Drought and striga tolerant maize varieties } \\
\text { Minimum tillage } \\
\text { Chemical fertiliser } \\
\text { Organic fertilizer } \\
\text { Manure application } \\
\text { Composting } \\
\text { Cross breeding/ Breed improvement/ selection } \\
\text { Supplementary feeding } \\
\text { Rotational grazing } \\
\text { Fodder banking } \\
\text { Farmer-managed Natural Regeneration } \\
\text { Mulching } \\
\text { Beekeeping } \\
\text { Half-moon and Zai } \\
\text { Intensive small holder pig farming } \\
\text { Guinea Fowl Ethno-veterinary health management } \\
\text { Combine mineral and organic nutrient management } \\
\text { Drip irrigation } \\
\text { Talking book } \\
\text { Essoko Ignitia Ltd Information Dissemination } \\
\text { Contour ploughing/farming } \\
\text { Proper storage } \\
\text { Inter/alley-cropping } \\
\text { Crop insurance } \\
\text { Cage fish farming }\end{array}$ & $\begin{array}{l}\sqrt{ } \\
V \\
V \\
V \\
V \\
V \\
V \\
V \\
V \\
V \\
V \\
V \\
V \\
V \\
V \\
V \\
V \\
V \\
V \\
V \\
V \\
V \\
V \\
V \\
V \\
- \\
- \\
- \\
- \\
- \\
- \\
- \\
- \\
- \\
-\end{array}$ & 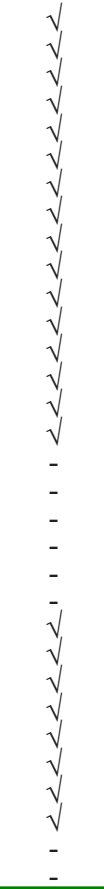 & $\begin{array}{l}V \\
V \\
V \\
V \\
V \\
V \\
V \\
V \\
V \\
V \\
V \\
V \\
V \\
V \\
V \\
V \\
V \\
V \\
V \\
V \\
V \\
V \\
V \\
V \\
V \\
V \\
V \\
V \\
V \\
V \\
V\end{array}$ \\
\hline
\end{tabular}


It was observed that the communities where these CSA technologies and practices were mostly used followed the order:

1. Lawra district: "Kanpuoh > Babile/ Kalsagri $>$ Dikpe $>$ Bewong $>$ Oribilli $>$ Lawra $>$ Eremon $=$ Tanchara $/$ Kunyukuo

2. Jirapa district: Doggoh $>$ Konzokalah $>$ Baazu/Tampaala $>$ Tuggoh $>$ Tizza/ Douri $>$ Hain $>$ Chepuri $>$ Jirapa

3. Nandom district: Guo $>$ Goziir $=$ Betaglu $>$ Walateng $>$ Bullegaun $=$ Nandomkpee $>$ Zedung $>$ Brutu/Ko

Kanpuoh, Doggoh and Guo in Lawra, Jirapa and Nandom districts respectively were observed as communities that use more CSA technologies and practices. This was highly expected because Bompare and Doggoh are CCAFS climate-smart villages (CSVs) promoting tried and tested CSA technologies and practices. Similarly, Kanpuoh and Guo are well-demarcated demonstration sites regulated by the traditional authorities and followed best practices such as non-burning, no tree felling and no charcoal burning. They also practice farmer-managed natural regeneration of vegetation.

\section{Prioritization of CSA technologies and practices}

The respondents were made to prioritise five best-bet from the long list of CSA technologies and practices identified using the CSA profiling manual (Sam et al., 2015). Table
3 presents the results from the prioritisation process and summarized as:

1. Lawra district (28): Crop-livestock integration >Community-led bushfire control > Stone lining (bonding) or ridging $>$ Composting $>$ Crop rotation.

2. Jirapa district (30): Crop-livestock integration $>$ Chemical fertilizer $>$ Mixed cropping $>$ Crop rotation $>$ Stone lining (bonding) or ridging

3. Nandom district (38): Communityled bushfire control > Crop-livestock integration $>$ Mixed cropping $>$ Agroforestry $>$ Crop rotation

It is evident that crop-livestock integration and crop rotation were commonly used in all three districts. The crop-livestock integration is highly practiced in the Lawra and Jirapa districts indicating that the farmers are engaged in both livestock and crop farming. Again, Lawra and Nandom districts are promoting community-led bushfire control confirming the earlier finding that Kanpuoh and Guo are noted for that practice. These results suggest preferences in CSA use vary for the select districts, affirming the established fact that CSA is location, area and site-specific (FAO, 2013; MoFA, 2015). This may therefore serve as a guide to the type of CSA technologies and practices to be promoted for various locations within the Guinea Savannah agro-ecological zone. 
TABLE 3

Prioritised CSA technologies and practices in the study districts

\begin{tabular}{llccc}
\hline No. & Name of technology/ practice & Lawra & Jirapa & Nandom \\
\hline 1 & Crop-livestock integration & $1^{\text {st }}$ & $1^{\text {st }}$ & $2^{\text {nd }}$ \\
2 & Community-led bushfire control & $2^{\text {nd }}$ & & $1^{\text {st }}$ \\
3 & Stone lining (bonding) or ridging & $3^{\text {rd }}$ & $5^{\text {th }}$ & \\
4 & Composting & $4^{\text {th }}$ & & \\
5 & Crop rotation & $5^{\text {th }}$ & $4^{\text {th }}$ & $5^{\text {th }}$ \\
6 & Mixed cropping & & $3^{\text {rd }}$ & $3^{\text {rd }}$ \\
7 & Chemical fertilizer & $2^{\text {nd }}$ & \\
8 & Agroforestry & & $4^{\text {th }}$ \\
\hline
\end{tabular}

Source: Compilation from Field Data

Use of CSA technologies and practices by scale and by gender

The study discovered that CSA use in three districts followed the order of small scale $>$ medium scale $>$ large scale (Table 4 ). Medium and large-scale farming systems least applied the prioritized CSA technologies and practices at the time of the study. Communityled bushfire control was not used at largescale farming levels in the Nandom District. Similarly, none of the prioritized CSA technologies and practices was applied at largescale farming levels in the Lawra District. It implies therefore that smallholder farmers dominated in the use of the prioritised CSA technologies and practices in the districts. This confirms the national situation that farming in Ghana is smallholder dominated (MoFA, 2017) and the fact that farming in the study area is done on small scale where farmers engage in subsistence production systems to ensure sustenance and food security (Jirapa Municipal Assembly, 2018; Lawra Municipal, 2018; Nandom District Assembly, 2018).

Results in Table 4 further revealed that there is no restriction among the gender regarding the use of the prioritized CSA technologies and practices. Both males and females have equal opportunities to use CSA in the districts. This confirms the finding from Botchway et al. (2015) that all the CSA technologies and practices were patronised by both men and women in the study districts. The males dominated in the use of most CSA technologies and practices. Specific cases are crop-livestock integration and crop rotation, which commonly cut across all study districts. The observed male dominance could largely be attributed to financial implications and ownership of land and livestock, which the females may be disadvantaged. According to the key informants, all females do not own land in Nandom district but the male youth do and it happens mostly in the form of "ownership by inheritance". It is a cultural belief that the females will marry and join their hushands who own lands. Also, the labor-intensive nature of most CSA technologies and practices could be another reason as affirmed in FAO and MoFA (2018) that the laborious nature in the use of some of the CSA practices restricts their usage by females.

On the other hand, females dominated in the use of community-led bushfire control, mixed cropping and Stone lining (bonding) or ridging. For Community-led bushfire control, the female dominance could be ascribed to their reluctance in taking risk and tend to undertake 
adequate prevention of wild and bush fires. The female dominance in Mixed cropping and Stone lining (bonding) or ridging could also be due to the fact that females are deeply involved in food security matters in households. Again,
FAO and MoFA (2018) pointed out that females need multiple crops to support household needs. They also have challenges with land access and tend to cultivate multiple crops per piece of land available.

TABLE 4

CSA Technologies and Practices Use by Scale and Gender

\begin{tabular}{|c|c|c|c|c|c|c|}
\hline \multirow[t]{3}{*}{ District } & \multirow{3}{*}{$\begin{array}{l}\text { Ranking of CSA Technology/ } \\
\text { Practice }\end{array}$} & \multicolumn{5}{|c|}{ Usage of CSA Technology and Practice } \\
\hline & & \multicolumn{3}{|c|}{ Scale of Application (\%) } & \multicolumn{2}{|c|}{ Gender (\%) } \\
\hline & & Small & Medium & Large & Males & Females \\
\hline \multirow[t]{5}{*}{ Lawra } & 1. Crop-livestock integration & 92 & 8 & - & 60 & 40 \\
\hline & $\begin{array}{l}\text { 2. Community-led bushfire } \\
\text { control }\end{array}$ & 92 & 8 & - & 40 & 60 \\
\hline & $\begin{array}{l}\text { 3. Stone lining (bonding) or } \\
\text { ridging }\end{array}$ & 92 & 8 & - & 40 & 60 \\
\hline & 4. Composting & 92 & 8 & - & 55 & 45 \\
\hline & 5. Crop rotation & 100 & - & - & 80 & 20 \\
\hline \multirow[t]{5}{*}{ Jirapa } & 1. Crop-livestock integration & 88 & 10 & 2 & 65 & 35 \\
\hline & 2. Chemical fertilizer & 60 & 25 & 15 & 80 & 20 \\
\hline & 3. Mixed cropping & 89 & 10 & 1 & 20 & 80 \\
\hline & 4. Crop rotation & 55 & 25 & 20 & 80 & 20 \\
\hline & $\begin{array}{l}\text { 5. Stone lining (bonding) or } \\
\text { ridging }\end{array}$ & 70 & 20 & 10 & 80 & 20 \\
\hline \multirow[t]{5}{*}{ Nandom } & $\begin{array}{l}\text { 1. Community-led bushfire } \\
\text { control }\end{array}$ & 95 & 5 & - & 40 & 60 \\
\hline & 2. Crop-livestock integration & 85 & 5 & 10 & 60 & 20 \\
\hline & 3. Mixed cropping & 90 & 5 & 5 & 45 & 55 \\
\hline & 4. Agroforestry & 80 & 15 & 5 & 85 & 15 \\
\hline & 5. Crop rotation & 80 & 15 & 5 & 85 & 15 \\
\hline
\end{tabular}

Source: Compilation from Field Data

CSA technologies and practices and major farm commodities involved

Table 5 presents the prioritised CSA technologies and practices and the major farm commodities on which they are used in the selected districts. It was evident that CSA technologies and practices were mainly used for the staples such as cereals (maize, sorghum and millet) and legumes (groundnuts and cowpea) and small ruminants. It, therefore, implies the CSA generally support food and income security. 
TABLE 5

CSA Technologies and Practices, andFarm Commodities

\begin{tabular}{lll}
\hline $\begin{array}{l}\text { No. } \\
\mathbf{1}\end{array}$ & $\begin{array}{l}\text { CSA technology/practice } \\
\text { Crop-livestock integration }\end{array}$ & $\begin{array}{l}\text { Major Farm Commodities Involved } \\
\text { Maize, Sorghum, Millet, Groundnut, Cowpea, Soya beans, Bambara } \\
\text { beans, Sheep, Goats, Cattle, Poultry. }\end{array}$ \\
$\mathbf{2}$ & $\begin{array}{l}\text { Community-led bushfire control } \\
\text { Maize, Sorghum, Millet, Groundnut, Yam, Sheep, Goats, Poultry. } \\
\mathbf{3}\end{array}$ & $\begin{array}{l}\text { Stone lining (bonding) or } \\
\text { Maize, Sorghum, Millet, Groundnut, Cowpea, Soya beans }\end{array}$ \\
& Ridging & \\
$\mathbf{4}$ & Composting & Maize, Sorghum, Millet, Sheep, Goats, Cattle, Poultry. \\
$\mathbf{5}$ & Crop rotation & Maize, Millet, Sorghum, Groundnut, Cowpea, Soya beans. \\
$\mathbf{6}$ & Mixed cropping & Maize, Sorghum, Millet, Groundnuts, Cowpea, Yam, Rice, Soya \\
& beans, Bambara beans. \\
$\mathbf{7}$ & Chemical fertilizer & Maize, Sorghum, Millet, Rice, Soya beans. \\
$\mathbf{8}$ & Agroforestry & Leuceana, Cashew, Moringa, Mango, Maize, Sorghum, Millet, \\
& & Groundnuts, Cowpea, Soya beans.
\end{tabular}

Source: Compilation from Field Data

Costs and benefits associated with the use of CSA technologies and practices

From the results in Table 6, Crop-livestock integration had the highest cost of application in all the districts; Lawra = GH $\phi 6,370.00$, Jirapa $=$ GH $\phi 1,370.00$, Nandom $=\mathrm{GH} \phi 5,450.00$. The high cost involved in the crop-livestock integration system is partly due to the cost of acquiring and maintaining the animals, the cost of collecting and transporting manure and the cost of bringing crop residues to animals after harvesting. Similarly, crop rotation had the highest revenues in the Jirapa and Nandom districts but followed crop-livestock integration and community-led bushfire control in the Lawra District. Crop rotation is mostly done with mono-cropping systems and often for commercial purposes.

The benefits derived in the form of revenue generation were higher than the associated costs of using the CSA technologies and practices apart from composting. It implies therefore that, holding other things constant adoption of CSA technologies increased revenue of farmers in the Lawra, Jirapa and Nandom districts.

Net returns or worth, profit margins and benefit-cost ratio of using the CSA

In Table 6, the results established that crop-livestock integration had the lowest profit margins and benefit-cost ratio in all the three districts. On the other hand, crop rotation had the highest net return, profit margin and benefit-cost ratio in the Jirapa and Nandom districts but followed community-led bushfire control in the Lawra District. Composting showed a deviation in the observed trend with negative net return, negative profit margin $(\mathrm{PM}<0)$ and the lowest benefit-cost ratio, less than one (0.83). This implies the compost used in the Lawra district is not profitable and the investment is not financially viable.

The study further discovered that all the prioritised CSA technologies and practices had positive net returns or worth; only composting 
recorded negative net returns (-GHф680.00). This means that there are gains from using CSA technologies and practices except composting. Both the profit margins and benefit-cost ratios confirmed the validity of the above finding. Almost all the prioritised CSA technologies and practices recorded profit margins greater than zero but less than one. Similarly, almost all the prioritised CSA technologies and practices recorded benefit-cost ratios greater one. Again, only composting (Lawra district) showed a deviation in the observed trends in the financial analysis. These results conform with the findings from Andrieu et al. (2017), where the cost-benefit analysis showed that all the CSA practices generate economic benefits, except compost. To them, compost resulted in a negative net return and limited economic benefits, due to productivity or yield response lag. The choice of compost was largely due to its higher adaptation and mitigation potential (Andrieu et al., 2017) as well as the organic farm commodities it produces. It could therefore be inferred that ceteris paribus, using the CSA technologies and practices in the three districts has net gains; the investments are profitable and deemed financially viable.

Even though crop-livestock integration recorded the lowest profit margin and benefitcost ratio making its investment least profitable and financially viable, it was the most highly prioritized practice among the CSA users within the study districts. This implies that the use of the crop-livestock integration system was not based only on monetary value but on other factors such as food security and sociocultural considerations like funerals, festivals, dowry or bride price, traditional sacrifices and insurance against crop failure. 
TABLE 6

Analysis of Costs and Benefits Associated with using Top

CSA Technologies and Practices in the Study Area

\begin{tabular}{|c|c|c|c|c|c|c|}
\hline District & $\begin{array}{l}\text { Name of CSA } \\
\text { Technology/Practice }\end{array}$ & $\begin{array}{c}\text { Estimated } \\
\text { Cost }(G H \phi)\end{array}$ & $\begin{array}{c}\text { Estimated } \\
\text { Revenue } \\
\text { (GHc) }\end{array}$ & $\begin{array}{c}\text { Net } \\
\text { Returns } \\
(G H \phi)\end{array}$ & $\begin{array}{c}\text { Profit } \\
\text { Margins }\end{array}$ & $\begin{array}{c}\text { Benefit-Cost } \\
\text { Ratio }\end{array}$ \\
\hline \multirow{5}{*}{ Lawra } & $\begin{array}{l}\text { 1. Crop-livestock } \\
\text { integration }\end{array}$ & $6,370.00$ & $6,920.00$ & 550.00 & 0.0795 & 1.0863 \\
\hline & $\begin{array}{l}\text { 2. Community-led } \\
\text { bushfire control }\end{array}$ & $2,400.00$ & $6,920.00$ & $4,520.00$ & 0.6532 & 2.8833 \\
\hline & 3. Stone lining & $1,100.00$ & $2,620.00$ & $1,520.00$ & 0.5802 & 2.3818 \\
\hline & 4. Composting & $4,000.00$ & $3,320.00$ & -0680.00 & -0.2048 & 0.8300 \\
\hline & 5. Crop rotation & $2,380.00$ & $6,220.00$ & $3,840.00$ & 0.6174 & 2.6134 \\
\hline \multirow{5}{*}{ Jirapa } & $\begin{array}{l}\text { 1. Crop-livestock } \\
\text { integration }\end{array}$ & $1,430.00$ & $3,640.00$ & $2,210.00$ & 0.6071 & 2.5455 \\
\hline & 2. Chemical fertilizer & 900.00 & $3,600.00$ & $2,700.00$ & 0.7500 & 4.0000 \\
\hline & 3. Mixed cropping & 435.00 & $2,240.00$ & $1,805.00$ & 0.8058 & 5.1494 \\
\hline & 4. Crop rotation & 715.00 & $4,480.00$ & $3,765.00$ & 0.8404 & 6.2657 \\
\hline & $\begin{array}{l}\text { 5. Stone lining } \\
\text { (bonding) or ridging }\end{array}$ & 475.00 & $2,960.00$ & $2,410.00$ & 0.8142 & 5.3818 \\
\hline \multirow{5}{*}{ Nandom } & $\begin{array}{l}\text { 1. Community-led } \\
\text { bushfire control }\end{array}$ & $3,400.00$ & $5,990.00$ & $2,590.00$ & 0.4324 & 1.7618 \\
\hline & $\begin{array}{l}\text { 2. Crop-livestock } \\
\text { integration }\end{array}$ & $5,450.00$ & $8,900.00$ & $3,450.00$ & 0.3876 & 1.6330 \\
\hline & 3. Mixed cropping & $3,300.00$ & $9,200.00$ & $5,900.00$ & 0.6413 & 2.7879 \\
\hline & 4. Agroforestry & $3,050.00$ & $7,890.00$ & $4,840.00$ & 0.6134 & 2.5869 \\
\hline & 5. Crop rotation & $1,500.00$ & $9,460.00$ & $7,960.00$ & 0.8414 & 6.3067 \\
\hline
\end{tabular}

Source: Compilation from Field Data

Contribution of the CSA technologies and practices to livelihood improvement

Aside from revenue generation, the use of CSA technologies and practices also provided other forms of benefits through contribution to livelihood improvement in the study area. These contributions were grouped into broad themes as improved farm yield, improved food security, improved living standard and improved soil fertility.
In general, using the CSA technologies and practices resulted in improvement in the farm yields followed by improvement in food security (Table 7). This is partly so because the farmers were largely smallholders using CSA in small-scale farming systems. Their priority is to ensure sustenance and food security, hence engage in subsistence production systems. 
TABLE 7

Ranked order of Contribution of-CSA Technologies and Practices to Livelihood Improvement

\begin{tabular}{|c|c|c|c|c|c|}
\hline \multirow[t]{2}{*}{ District } & \multirow[t]{2}{*}{ Name of CSA Technology/Practice } & \multicolumn{4}{|c|}{ Contribution by rank to livelihood improvement } \\
\hline & & $\begin{array}{l}\text { Improved } \\
\text { farm yield }\end{array}$ & $\begin{array}{l}\text { Improved } \\
\text { food } \\
\text { security }\end{array}$ & $\begin{array}{c}\text { Improved } \\
\text { living } \\
\text { standard }\end{array}$ & $\begin{array}{c}\text { Improved } \\
\text { soil } \\
\text { fertility }\end{array}$ \\
\hline \multirow[t]{5}{*}{ Lawra } & 1. Crop-livestock integration & $1^{\text {st }}$ & $3^{\text {rd }}$ & $2^{\text {nd }}$ & $4^{\text {th }}$ \\
\hline & 2. Community-led bushfire control & $3^{\text {rd }}$ & $2^{\text {nd }}$ & $1^{\text {st }}$ & $4^{\text {th }}$ \\
\hline & 3. Stone lining (bonding) or ridging & $1^{\text {st }}$ & $2^{\text {nd }}$ & $4^{\text {th }}$ & $3^{\text {rd }}$ \\
\hline & 4. Composting & $2^{\text {nd }}$ & $3^{\text {rd }}$ & $4^{\text {th }}$ & $1^{\text {st }}$ \\
\hline & 5. Crop rotation & $1^{\text {st }}$ & $2^{\text {nd }}$ & $3^{\text {rd }}$ & $4^{\text {th }}$ \\
\hline \multirow[t]{5}{*}{ Jirapa } & 1. Crop-livestock integration & $2^{\text {nd }}$ & $3^{\text {rd }}$ & $4^{\text {th }}$ & $1^{\text {st }}$ \\
\hline & 2. Chemical fertilizer & $1^{\text {st }}$ & $3^{\text {rd }}$ & $2^{\text {nd }}$ & $4^{\text {th }}$ \\
\hline & 3. Mixed cropping & $1^{\text {st }}$ & $2^{\text {nd }}$ & $4^{\text {th }}$ & $3^{\text {rd }}$ \\
\hline & 4. Crop rotation & $1^{\text {st }}$ & $3^{\text {rd }}$ & $4^{\text {th }}$ & $2^{\text {nd }}$ \\
\hline & 5. Stone lining (bonding) or ridging & $2^{\text {nd }}$ & $1^{\text {st }}$ & $2^{\text {nd }}$ & $1^{\text {st }}$ \\
\hline \multirow[t]{5}{*}{ Nandom } & 1. Community-led bushfire control & $4^{\text {th }}$ & $3^{\text {rd }}$ & $1^{\mathrm{st}}$ & $2^{\text {nd }}$ \\
\hline & 2. Crop-livestock integration & $4^{\text {th }}$ & $1^{\text {st }}$ & $2^{\text {nd }}$ & $3^{\text {rd }}$ \\
\hline & 3. Mixed cropping & $3^{\text {rd }}$ & $1^{\mathrm{st}}$ & $2^{\text {nd }}$ & \\
\hline & 4. Agroforestry & $4^{\text {th }}$ & $1^{\text {st }}$ & $3^{\text {rd }}$ & $2^{\text {nd }}$ \\
\hline & 5. Crop rotation & $1^{\text {st }}$ & $3^{\text {rd }}$ & $2^{\text {nd }}$ & $2^{\text {nd }}$ \\
\hline
\end{tabular}

Source: Compilation from Field Data

Challenges associated with the utilization of CSA technologies and practices

The respondents mentioned and ranked numerous challenges associated with using the CSA technologies and practices in the districts. Among the key challenges encountered in the respective districts are the following:

1. Lawra district key challenges include: Poor and erratic rainfall pattern $>$ Cross border bushfires from the neighbourhood $>$ inappropriate tools and materials.

2. Jirapa district key challenges include: inadequate farmlands $>$ high capital investment $>$ increased acidity and alkalinity.

3. Nandom district key challenges include: Inadequate technical know-how $>$ Poor and erratic rainfall pattern $>$ inappropriate tools and materials
Poor and erratic rainfall patterns, inadequate technical knowledge and inappropriate tools and materials appeared to hinder the smooth implementation of CSA in the study districts.

Some identified support systems required to promote CSA within the study area

The study identified some support systems necessary to promote CSA adoption within the study area. Table 8 presents details of some local level policy recommendations made by the respondents in support of CSA promotion within the districts. In general, there was the need to develop, implement and enforce community bye-laws on bushfires, deforestation and animal confinement at the community-level. Both the district and national levels need to strengthen extension and advisory service delivery systems through promotional education and training campaigns. The national level also needs to ensure adequate 


\section{research into improved crop varieties and law enforcement and adequate funding for animal breeds, provide input supply subsidies CSA.} and ensure effective policy implementation,

\section{TABLE 8}

Local Level Policy Recommendations made by Respondents in Support of CSA

\begin{tabular}{|c|c|c|c|c|}
\hline No. & CSA Practice & Community Level & District Level & National Level \\
\hline \multirow[t]{3}{*}{1} & $\begin{array}{l}\text { Crop-livestock } \\
\text { integration. }\end{array}$ & $\begin{array}{l}\text { Develop and implement } \\
\text { bye-laws on bushfires, tree } \\
\text { felling, animal confinement. }\end{array}$ & $\begin{array}{l}\text { Enact, gazette and enforce } \\
\text { bye-laws. }\end{array}$ & $\begin{array}{l}\text { Implement policies and enforce } \\
\text { laws. }\end{array}$ \\
\hline & & $\begin{array}{l}\text { Promote non-burning of crop } \\
\text { residues. }\end{array}$ & $\begin{array}{l}\text { Increase extension education } \\
\text { and training. }\end{array}$ & $\begin{array}{l}\text { Strengthen extension and advisory } \\
\text { service systems. }\end{array}$ \\
\hline & & Maintain water bodies. & $\begin{array}{l}\text { Upscale the livestock in- } \\
\text { kind intervention to several } \\
\text { communities. }\end{array}$ & $\begin{array}{l}\text { Initiate alternative livelihood } \\
\text { schemes aside crop production. }\end{array}$ \\
\hline 2 & $\begin{array}{l}\text { Community-led } \\
\text { bushfire control }\end{array}$ & $\begin{array}{l}\text { Build farmers' capacity. } \\
\text { Develop and implement } \\
\text { bye-laws on bushfires and } \\
\text { deforestation. }\end{array}$ & $\begin{array}{l}\text { Enact, gazette and enforce } \\
\text { bye-laws on bushfires and } \\
\text { deforestation. }\end{array}$ & $\begin{array}{l}\text { Supply adequate funding. } \\
\text { Strengthen the district assemblies to } \\
\text { enforce environmental laws. }\end{array}$ \\
\hline 3 & $\begin{array}{l}\text { Stone lining } \\
\text { (bonding) or } \\
\text { Ridging }\end{array}$ & $\begin{array}{l}\text { Community stone lining } \\
\text { on most affected areas. } \\
\text { Compulsory use of the } \\
\text { practice for increase yield. }\end{array}$ & $\begin{array}{l}\text { Promote farming as business. } \\
\text { Promote the practice for } \\
\text { improved yield. }\end{array}$ & $\begin{array}{l}\text { Support district assemblies to } \\
\text { promote the practice for maximum } \\
\text { yield. }\end{array}$ \\
\hline 4 & Composting & $\begin{array}{l}\text { Build farmers' capacities in } \\
\text { the use of the practice. }\end{array}$ & $\begin{array}{l}\text { Increase extension education } \\
\text { and training. }\end{array}$ & $\begin{array}{l}\text { Strengthen extension and advisory } \\
\text { service systems. } \\
\text { Implement policies and enforce } \\
\text { laws. }\end{array}$ \\
\hline \multirow[t]{2}{*}{5} & Crop rotation & $\begin{array}{l}\text { Develop and implement bye- } \\
\text { laws on bushfires Cultivate } \\
\text { approved crop varieties }\end{array}$ & $\begin{array}{l}\text { Enact/gazette and enforce } \\
\text { bye-laws on bushfires and } \\
\text { deforestation }\end{array}$ & $\begin{array}{l}\text { Strengthen extension and advisory } \\
\text { service systems. }\end{array}$ \\
\hline & & & $\begin{array}{l}\text { Make crop varieties available } \\
\text { for all year round cultivation }\end{array}$ & $\begin{array}{l}\text { Make improved crop varieties } \\
\text { available and affordable. }\end{array}$ \\
\hline \multirow[t]{3}{*}{6} & Mixed cropping & $\begin{array}{l}\text { Use of improved crop } \\
\text { varieties }\end{array}$ & $\begin{array}{l}\text { Increase extension education } \\
\text { and training }\end{array}$ & $\begin{array}{l}\text { Supply adequate funding } \\
\text { Research to improve the technology. }\end{array}$ \\
\hline & & & $\begin{array}{l}\text { Link farmers to improved } \\
\text { crop varieties }\end{array}$ & $\begin{array}{l}\text { Strengthen extension and advisory } \\
\text { service systems. }\end{array}$ \\
\hline & & & & $\begin{array}{l}\text { Make improved varieties available } \\
\text { and affordable. }\end{array}$ \\
\hline \multirow[t]{3}{*}{7} & Chemical fertilizers & $\begin{array}{l}\text { Farmer education on proper } \\
\text { use of chemical fertilizers. }\end{array}$ & $\begin{array}{l}\text { Implement environmental } \\
\text { safety policies. }\end{array}$ & $\begin{array}{l}\text { Implement policies and enforce } \\
\text { laws. }\end{array}$ \\
\hline & & & $\begin{array}{l}\text { Regulate prices and control } \\
\text { smuggling. }\end{array}$ & $\begin{array}{l}\text { Need for environmental safety } \\
\text { policies and implementation. }\end{array}$ \\
\hline & & & $\begin{array}{l}\text { Provide education for input } \\
\text { dealers. }\end{array}$ & Provide inputs subsidies. \\
\hline
\end{tabular}


8 Agroforestry Practice non-burning.

Develop and implement bye-laws on bushfires and deforestation.
Support community-based bushfire control.

Enact/gazette and enforce bye-laws on bushfires and deforestation.
Strengthen extension and advisory service systems.

Adequate input supply.

Support district assemblies to enact laws against environmental degradation.

\section{Source: Compilation from Field Data}

\section{Conclusion and Recommendation}

The study has demonstrated that the utilisation of CSA technologies and practices in the Lawra, Jirapa and Nandom districts of Ghana is cost-effective and beneficial. CSA use in these districts is largely smallholder-driven and both males and females have equal opportunity to use. Males dominated in most CSA technologies and practices partly due to financial implications, ownership of land and livestock and the intensive labour requirement. Females dominated in few due partly to their involvement in household food security matters and reluctance in taking risk leading to taking adequate wild and bush fires preventive measures. There are gains from using prioritised CSA technologies and practices. CSA investments are profitable and financially viable indicating that CSA users are better of than otherwise. Aside the financial gains, CSA use, in general, leads to livelihood improvement; however, the incidence of bush or wild fires, inadequate technical knowledge, inter alia tend to constrain CSA adoption in the study districts.

It is recommended that the District assemblies and the Departments of agriculture must join forces to promote CSA use within the districts. Adequate research is required to make tried and tested CSA technologies and practices available for promotion. CSA use by both males and females in the districts presents added opportunity to embark on rigorous promotional campaigns for effective CSA adoption. This could begin with the local media and through the agricultural extension agents. Capacity building at all levels of CSA discourse is very crucial. Community-level people must develop, implement and enforce bye-laws on bushfires, deforestation and animal confinement. Both the district and national levels must strengthen extension and advisory service delivery systems through promotional education and training campaigns. The government must support adequate research into improved crop varieties and animal breeds, supply input subsidies, ensure effective policy implementation and law enforcement and provide adequate funding for CSA actions. Measures must therefore be put in place to ensure that these trickle down to the districts and the communities where CSA actions are implemented.

\section{Acknowledgement}

We are grateful to the CGIAR Research Programme on Climate Change Agriculture and Food Security (CCAFS) in the West Africa Region hosted by the International Crops Research Institute for the Semi-Arid Tropics (ICRISAT), Bamako, Mali for the financial and technical support. We also appreciate the numerous supportive services of Ghana CCAFS Platform. The District Level Platforms in the Lawra, Jirapa and Nandom Districts are duly acknowledged for assisting in the data collection. 


\section{REFERENCES}

Adiku, S. G. K., MacCarthy, D. S., Haithie, I., Diancoumba, M., Freduah, B. S., Amikuzuno, J., Traore, P. C. S., Traore, S., Koomson, E., Agali, A., Lizaso, J. I., Fatondji, D., Adams, M., Tigana, L., Diarra, D. Z., N'diaye, O. \& Valdiva, R. O. (2015) Climate Change Impacts on West African Agriculture: An Integrated Regional Assessment. In (eds) Rosenzweig C. and Hillel D. Handbook of Climate Change and Agroecosystems: The Agricultural Model Intercomparison and Improvement Project (AgMIP) Integrated Crop and Economic Assessments - Joint Publication with the American Society of Agronomy, Crop Science Society of America, and Soil Science Society of America.. Imperial College Press, London, $25-73$.

Andrieu, N., Sogoba, B., Zougmore, R., Howland, F., Samake, O., Bonilla-Findji O., Lizarazo, M., Nowak, A., Dembele, C. \& CornerDolloff C. (2017) Prioritizing investments for climate-smart agriculture: Lessons learned from Mali. Agricultural Systems. Elsevier B.V. journal homepage: www.elsevier.com/locate/ agsy

Anuga S. W., Gordon, C., Boon, E. \& Surugu, J. M-I. (2019) Ghana Journal of Geography 11 (1), 124 - 139 DOI: https://dx.doi.org/10.4314/ gjg.v11i1.8

Asante, F. A. \& Amuakwa-Mensah F. (2015) Climate Change and Variability in Ghana: Stocktaking. Climate 3, 78 - 99; doi:10.3390/cli3010078.

Awosi, P. (2017) The Effects of Drought on the Livelihood of Rural Households in the Nandom District of the Upper West Region, Ghana. Thesis for Master of Philosophy Degree. University for Development Studies. Ghana.

Botchway, V. A., Karbo, N., Sam, K. O., Nutsukpo, D. K. \& Zougmore, R. (2015) Profile of Climate Smart Agricultural Technologies in the Guinea Savannah and Forest AgroEcological Zones in Ghana. Ghana Society of Animal Production. 19 $9^{\text {th }}$ Biennial Conference $5^{\text {th }}-8^{\text {th }}$ August, 2015. Cape Coats, Ghana

CIAT: BFS/USAID. (2016) Climate-Smart Agriculture in Senegal. CSA Country Profiles for Africa Series. International Center for Tropical Agriculture (CIAT); Bureau for Food Security, United States Agency for International Development (BFS/USAID), Washington, D.C. p. 20.

De Pinto, A., Demirag, U., Haruna, A., Koo, J. \& Asamoah, M. (2012) Climate change, agriculture, and foodcrop production in Ghana (Policy Note 3). Retrieved from International Food Policy Research Institute website: http:// www.ifpri.org/publication/climatechange agriculture-and-foodcrop-production-ghana.

Dyson, J. R. (1997) Accounting for Non-Accounting Students, $4^{\text {th }}$ Edition. Department of Accountancy and Finance, Heriot-Watt University, Edinburgh. Financial Time. Prentice Hall. An Imprint of Pearson Education Ltd., Harlow, England, London.

Essegbey, G. O. \& MacCarthy, D.S. (2020) Situational Analysis Study for the Agriculture Sector in Ghana. Technical Reports. CGIAR Research Programme on Climate Change, Agriculture and Food Security (CCAFS) West Africa, Bamako, Mali.

Food and Agriculture Organization (FAO) of United Nations (2013) Climate-Smart Agriculture Sourcebook. United Nations FAO.

Food and Agriculture Organization (FAO) of United Nations (2015) Sourcebook on Climate-Smart Agriculture, Forestry and Fisheries.http://www. fao.org/climate-smart-agriculture/72611/en/. Climate-Smart Agriculture, 2015.

Food and Agriculture Organization (FAO) of United Nations and Ministry of Food and Agriculture (MoFA) (2018) Investment 
Framework for Mobilisation of Resources into Climate Smart Agriculture (CSA) in Ghana.

Freduah, B. S., MacCarthy, D. S., Adam, M., Ly, M., Ruane, A. C., Timpong-Jones, E. C., Traore, P. S., Boote, K. J., Porter, C. \& Adiku, S. G. K. (2019) Sensitivity of Maize Yield in Smallholder Systems to Climate Scenarios in Semi-Arid Regions of West Africa: Accounting for Variability in Farm Management Practices. Agronomy 9 (10), p. 639.http://doi.org/10.3390/agronomy9100639

Ghana Climate Change, Agriculture and Food Security - GCCAFS (2014) GCCAFS Platform Review 1 (2), October - December 2014.

Ghana Statistical Service - GSS (2020) Rebased 2013 - 2019 Annual Gross Domestic Product, GSS, Accra, Ghana. www.statsghana.gov.gh

Ghawate, N. P. (2020) Micro Economics: Production Function, Types of Cost and Revenue Concept. PowerPoint Presentation. University of Pune, C. T. Bora College shirur Department of Economics.

Gittinger, J. P. (1982) Economic Analysis of Agricultural Projects, $2^{\text {nd }}$ Edition. Published for the Economic Development Institute of the World Bank. The John Hopkins University Press, Baltimore and London.

Issahaku, Z. A. \& Maharjan, K. L. (2014) Crop substitution behavior among food crop farmers in Ghana: an efficient adaptation to climate change or costly stagnation in traditional agricultural production system? Agricultural and Food Economics 2 (1), p. 16.

Jirapa District (2014) Population and Housing Census for 2010. District Analytical Report. Ghana Statistical Service, October 2014.

Jirapa Municipal Assembly (2018) District Medium Term Development Plan. 2018 - 2021.
Karbo, N., Botchway, V. A., Essegbey, G. O., Sam, K. O., Nutsukpo, D. K., Zougmoré, R. \& Akuffobea, M. (2016) Climate-Smart Agriculture Practices and Technologies in Ghana. Ghana National Climate Change Science-Policy Dialogue Platform.

Koutsoyiannis, A. (1979) Modern Microeconomics. Second Edition, Printed in Hong Kong, Macmillan Publishers Limited, London, U. K.

LaRock, H. (2019) How to Calculate Total Cost in Economics. Updated May 14, 2019. https:// www.theclassroom.com/how-to-calculatetotal-cost-in-economics-13645626.htmlTuesday $7^{\text {th }}$ July 2020, 17:10.

Lawra District (2014) Population and Housing Census for 2010. District Analytical Report. Ghana Statistical Service, October 2014.

Lawra Municipal Assembly (2018) District Medium Term Development Plan. 2018 - 2021.

Ministry of Environment, Science, Technology and Innovation - MESTI (2013) Ghana National Climate Change Policy. Republic of Ghana.

Ministry of Food and Agriculture - MOFA (2015) National Climate-Smart Agriculture Action Plan (2016-2020). Ministry of Food and Agriculture. Republic of Ghana. Website www.mofa.gov.gh

Ministry of Food and Agriculture - MOFA (2017) Agricultural Sector Progress Report. Ministry of Food and Agriculture. Republic of Ghana.

Nandom District (2014) Population and Housing Census for 2010. District Analytical Report. Ghana Statistical Service, October 2014.

Nandom District Assembly (2018) District Medium Term Development Plan. 2018 - 2021. 
Nwokoye, E. S. \& Ilechukwu, N. I. (2018) Principles of Economics 1 Chapter Five, Theory of Costs. August, 2018. https://www.researchgate.net/ publication/326841533 CHAPTER FIVE THEORY OF COSTS . Tuesday $\overline{7}^{\text {th }}$ July 2020, 17:10.

Sam, K. O., Botchway, V. A. \& Karbo N. (2015) Technologies and Practices for Climate-Smart Agriculture (CSA): A Participatory Profiling Manual. Ghana CCAFS Science-Policy Dialogue Platform, Accra.
Sijmons, K., Kiplimo, J., Forch, W., Thornton P. K., Moussa, A. S. \& Zougmoré, R. (2013) CCAFS Site Atlas - Lawra-Jirapa/Lawra. CCAFS site atlas series. The CGIAR Research Program on Climate Change, Agriculture and Food Security (CCAFS). Copenhagen, Denmark. Available online at: www.ccafs. cgiar.org www.elsevier.com/locate/agsy

Thornton P. K., Boone R. B. \& Ramirez-Villegas, J. (2015) Climate change impacts on livestock. CCAFS Working Paper no. 120. CGIAR Research Program on Climate Change, Agriculture and Food Security (CCAFS). Copenhagen, Denmark. Available online at: www.ccafs.cgiar.org 